\title{
Development of Learning Activities Playing a Ball on a Goal To Improve Manipulative Skills For Lower Class Students
}

\author{
${ }^{1}$ Irfan Dedik Purnomo, ${ }^{2}$ Tomoliyus, ${ }^{3}$ Erick Burhaein \\ 111711251042@student.uny.ac.id, 2tomoliyus@uny.ac.id, ${ }^{3}$ erick.burhaein2016@ student.uny.ac.id \\ ${ }^{1,3}$ Sport Science, Post Graduation Program, Universitas Negeri Yogyakarta \\ ${ }^{2}$ Sport Science Faculty, Universitas Negeri Yogyakarta
}

\begin{abstract}
This study aims to develop the learning activities of throwing the ball at the target to improve manipulative skills for lower grade students. This research is a development research consisting of two stages namely preliminary research stage and development stage. The preliminary research stage consists of a literature review, relevant research studies and field studies. Development stage consists of planning, expert validation, small-scale test, and large-scale test. Validation involves 4 experts. Small-scale test conducted on 10 students of grade 1 and 2 by involving 2 teachers at SD N 1 Banjarharjo. Large-scale tests were conducted on two elementary schools namely SD N Jatimulyo and SD N Semuten using 20 students in each school and 4 teachers. The instruments used are questionnaires, observation sheets, and assessment rubrics. Data analysis at the preliminary research stage and development stage using qualitative and quantitative descriptive analysis techniques. The results of this study in the form of learning activities to throw a ball on the target to improve manipulative skills for lower class students as much as 4 game models. Based on the assessment of expert validation stated that the content of materials, language, and writing format in the learning model is very good. The results of small-scale tests in substance and implementation are very good. The results of large-scale tests of substance and implementation aspects are very good, resulting in a decent model to use. Different test results on student manipulative basic motion were found to increase significantly from meeting 1 to meeting 2 to meeting 3 . The average score at the 3rd meeting was highest compared to the 1 st and 2nd meetings. It can be concluded that the learning activity of playing the ball to the effective target to develop basic manipulative motion of lower grade elementary school students.
\end{abstract}

Keywords:game throwing ball, manipulative motion, primary school

\section{Introduction}

Sports and Health Physical Education Teachers must be able to create a conducive, creative, innovative and fun learning atmosphere for students. So that students want to follow the learning process well and the goals of the learning process can be achieved. If the teacher is unable to create interesting learning models, then a conducive learning atmosphere and learning objectives will be difficult to achieve. During learning, of course there are obstacles experienced by teachers, especially for elementary school level in lower class students. Most lower-class students feel lazy and are reluctant to take part in Sports and Health Physical Education. Even though at that age, children have a high desire for movement.

Hadith[1], states that the low learning interest of students is influenced by learning object factors, methods, strategies, learning approaches used, teacher attitudes and behavior, learning media, learning facilities, learning environments and so on. Judging from the object 
learning factors, the problem experienced by lower class students are fear, shame and lack of ability to express themselves. Judging from the teacher's factors, many teachers do not make creative in creating learning models, which is the cause of students' low enthusiasm in taking lessons.

Sports Physical and Health Education subjects are one of the subjects held at the elementary or elementary school level. Sports Physical Education and Health is an integral part of education as a whole, which aims to develop aspects of physical fitness, motion skills, critical thinking skills, social skills, reasoning, emotional stability, moral actions, aspects of healthy lifestyles and the introduction of a clean environment through physical activity, selected sports and health are planned systematically in order to achieve national education goals. Buscemi[2], mentions "incorporating physical activity into school day results in positive outcomes. Physical activity helps school-aged children stay fit and healthy.

Education is a process of human development that lasts a lifetime. Sports and Health Physical Education taught in schools has a very important role, which is to provide opportunities for students to be directly involved in various learning experiences through physical, sports and health activities that are selected and carried out systematically. Debriefing the learning experience is directed to foster better physical growth and psychic development, while forming a healthy and fit lifestyle throughout life. Faigenbaum \& Mediate[3], said "Children and adolescents need to participate regularly in physical activities that enhance and maintain cardiovascular and musculoskeletal health". Basically the Physical Education and Health subjects are an educational process through physical activity. Through this learning process, Physical Education wants to contribute to children's development, a development that is not biased. Comprehensive development, because only the physical or physical aspects are intended. But also the development of motion or psychomotor, the development of knowledge and reasoning included in cognitive terms, as well as the development of character and personality, which are included in the terms of affective development.

The implementation of education as a process of human development that lasts a lifetime. Sports Physical Education and Health have a very important role, which provides opportunities for students who are directly involved in various learning experiences through physical activities that are carried out systematically. Debriefing the learning experience is directed to stimulate the student's basic movements, while forming a healthy and active lifestyle throughout life. Motion stimulation is very appropriate if given to lower grade elementary school students. In general they are at the age of 6-7 years, besides that because the stimulation of the right motion will determine the quality of motion.

According to Widya[4], the development of basic motion is a process to obtain motion that always develops based on the process of developing nerves and muscles and the consequences of previous motion experience. The following are the stages of motion behavior from 0 years to adulthood.The importance of mastering basic movements for elementary school students must get the attention of the teacher. A teacher of the Physical Education must be able to provide stimulation or develop basic movements of students. this can especially be done during the PASS learning process using forms or learning models that are interesting and easy to do by students. But the situation on the ground is not always as idealized. In rural areas such as in the District of Dlingo, for example, most Sports and Health Physical Education teachers are less attractive in presenting learning models to students.

They have not used game models in delivering material. Teachers pay less attention to this, as a result students are less enthusiastic and bored quickly in participating in learning activities. This also resulted in lack of mastery of the basic movements of students. Viewed 
from the standpoint of students, most students like favorite sports games like football. Students are very enthusiastic about learning when the material being taught is a sport that is a favorite and loved. Some students don't even want to stop until the lesson is over.Problems are faced when the teacher must convey unpopular sports material. Students usually tend to be lazy and not eager to follow the learning process. In basic movement materials, for example, most teachers only deliver material according to the guidelines from the physical education book.

This condition is often less attractive and boring for students. The impact is that students are less interested in participating in learning so that the results achieved become less than optimal. In terms of facilities and infrastructure, most of the Physical, Sports and Health Education teachers in Dlingo District complained about the lack of sports facilities and infrastructure in their schools. Most schools do not have complete infrastructure. This condition can hamper the learning process carried out by the teacher.Various problems faced by the teacher can actually be solved if they have creativity in developing learning models. Lack of student interest in sports material that is less popular can be overcome by modifying the learning model that is adapted to the characteristics of elementary school students. Basically, elementary school children have the characteristics of playing, so that the elements of the game can be included in the learning model that is adapted to the given sports material.

Limitations of infrastructure facilities can be overcome by using media that is easily obtained in the surrounding environment such as balls, cardboard, wooden boards and so on according to the needs of the game learning model conducted by the teacher.Therefore, it is important to develop learning activities to throw ball for lower-grade elementary school students to improve basic manipulative movement skills.

\section{Literature Review}

\subsection{Playing activities}

Playing activities can affect child development. The benefits of playing for the development of the child stated by Mutiah[5], are as follows:

a. Playing creates an actual ability.

b. Playing facilitates the separation of thoughts from objects and actions.

c. Playing develops self-mastery, children act in scenarios, and cannot be arbitrary. The benefits of playing according to Tedjasaputra[6], are as follows:

d. Improving the development of physical aspects, activities that involve movement make the child's body healthy.

e. Improve the development of gross motor and fine motor aspects. Improve the development of social aspects. Children learn about the value system, habits and moral standards of society.

f. Improve the development of emotional or personality aspects. Playing can help the formation of a positive self-concept, confidence and self-esteem.

g. Improve the development of cognitive aspects. Through playing children learn various kinds of basic concepts.

h. Sharpen sensing sharpness. Children become active, critical, and creative.

i. Develop sports skills. Physical development and gross and fine motor skills are very important as a basis for developing skills in the field of sports.

Based on the above opinion, it can be known that playing activities are beneficial for the child's development process. Playing can improve physical, motoric, social, emotional, cognitive, sensing and sports skills development. In addition to the benefits of being happy, a fit body, good physical skills and increased social skills. 


\subsection{Manipulative Skills}

The stage of development of movement skills for elementary school children is emphasized as the development and refinement of various basic movement skills and movement skills related to sports. Basic movements controlled by elementary school students, become the foundation for developing more complex movements. Basic movements in children form the basis for motion. There are three basic basic movements, namely locomotor, non-locomotor and manipulative[4].

According to Sucipto[7] Manipulative motion is a movement in which something is moved, for example throwing, catching, hitting, kicking and other movements related to throwing and catching something. Manipulative motion is motor skills that require eye coordination with other members of the body to anticipate places or objects to move. Forms of manipulative motion include rolling objects, throwing, catching, kicking and dribbling.

\section{Material \& Methodology}

\subsection{Participant}

The subjects tried in this study were teachers of Physical Education, Sports and Health Primary Schools in Dlingo District, Bantul Regency. In accordance with the stages of the study, several stages of the data collection process will be carried out. In this research, the model was tested in the field, namely the trial of small and large scale models. Small scale trials were conducted on 10 students. Large scale tests were carried out in 2 schools, each of which will be conducted on 20 students.

\subsection{Data Collection Procedure}

The development procedure in this study is based on steps of development research according to Gall and Borg. According to Gall \& Borg[8] in conducting development research there are several steps that must be taken. These steps can be described as follows: (1) collection of research and information, (2) planning, (3) initial product development, (4) initial trial, (5) revision to compile the main product, (6) test try the main field, (7) revision to compile operational products, (8) trial of operational products, (9) revision of final products, and (10) implementation of development products. The steps of research and development based on Gall and Borg theory above in this study were simplified into 4 stages / steps, namely (1) the retirement research stage and (2) the expert validation stage, (3) the empirical validation stage, (4) effectiveness test. The simplification of the research step is based on the needs and conditions in the field, especially the characteristics of elementary school students and the limited time for research.

\subsection{Data analysis technique}

The data analysis technique used in this study is descriptive data analysis. There are two types of descriptive data analysis techniques performed. First is the analysis of quantitative descriptive data, this analysis is carried out to analyze the data from the observations of experts on the quality of the draft model that was compiled and analyzed by experts prior to the field trial.

Second, qualitative data analysis. This analysis is carried out on data from interviews with training teachers in providing advice or input on the game model that is prepared primarily in the field testing stage on a small scale or wide scale. The effectiveness test will be analyzed quantitatively using t-test statistical analysis to prove the effectiveness of the learning model on improving the students' basic ability to move. 


\section{Results and Discussion}

\subsection{Small Scale Testing}

The results of effectiveness in small-scale trials can be seen in Table 1 below:

Table 1.

$\mathrm{T}$ Test Results of Throwing Results on the Target

\begin{tabular}{|c|c|c|c|l|}
\hline Observation & average & t-count & Sig. & Information \\
\hline Trial 1 & 2,30 & \multirow{2}{*}{6,000} & 0,000 & Significant \\
\hline Trial 2 & 3,50 & \\
\hline
\end{tabular}

Based on the results of the analysis in Table 4 above, the t count value is 6,000 with a significance value of 0,000 . Because the significance value is less than 0.05 ( $p<0.05$ ), it can be interpreted as an effective learning model in improving manipulative basic motion for lower grade elementary school students.

\subsection{Large Scale Testing}

The ability of students is assessed as much as 3 times of observation for 3 times the implementation of the game model. The results of effectiveness on large scale tests can be seen in Table 2 .

Table 2.

$\mathrm{T}$ Test Results of Accuracy of Ball Throwing on Target Large Scale Test 1 and Test 2

\begin{tabular}{|c|c|c|c|l|}
\hline Observation & average & t-count & Sig. & Information \\
\hline Trial 1 & 2,27 & \multirow{2}{*}{7,895} & 0,000 & Significant \\
\hline Trial 2 & 3,42 & & \\
\hline
\end{tabular}

Based on the results of the analysis of the t test on observations 1 and 2 in the table above obtained $t$ count value of 7.895 with a significance value of 0.000 . Therefore the significance value is less than 0.05 ( $p<0.05)$, it means that there is a significant increase in the skill of throwing the ball at the target in manipulative basic motion learning for lower grade elementary school students.

Table 3.

T Test Results of Accuracy of Ball Throwing on Target Large-scale Test 2 and Test 3

\begin{tabular}{|c|c|c|c|l|}
\hline Observation & Average & t-count & Sig. & Information \\
\hline Trial 2 & 3,42 & \multirow{2}{*}{2,037} & 0,048 & Significant \\
\hline Trial 3 & 3,67 & 2,60 \\
\hline
\end{tabular}

Based on the results of the analysis of the t test on observations 2 and 3 in the table above obtained $t$ count value of 2.037 with a significance value of 0.048 . Therefore the significance value is less than 0.05 ( $p<0.05$ ), it means that there is a significant increase in the skill of throwing the ball at the target in manipulative basic motion learning for lower grade elementary school students. 
Table 4.

$\mathrm{T}$ Test Results of Accuracy of Ball Throwing on Target Large Scale Test 1 and Test 3

\begin{tabular}{|c|c|c|c|c|}
\hline Observation & average & t-count & Sig. & Information \\
\hline Trial 1 & 2,27 & \multirow{2}{*}{11,382} & 0,000 & Significant \\
\hline Trial 3 & 3,67 & &
\end{tabular}

Based on the results of the analysis of the t test on observations 1 and 3 in the table above obtained $t$ count value of 11,382 with a significance value of 0,000 . Therefore the significance value is less than 0.05 ( $\mathrm{p}<0.05)$, it can be interpreted as an effective learning model in improving ball throwing skills in the target in manipulative basic motion learning for lower grade elementary school students.

At the end of the large-scale test session, students were asked to fill out a motivation questionnaire to find out how far the motivation and enthusiasm of students in participating in learning by using the learning model applied. The results of students' motivation questionnaire answers after following the learning on a large scale test are as follows.

\subsection{Discussion}

The implementation phase of the development model begins with a small-scale trial. Small-scale trials were conducted on 10 students of SD N 1 Banjarharjo Dlingo Bantul. Subjects were taken from grade IV students. The trial was carried out in the school grounds of SDN 1 Banjarharjo Dlingo Bantul accompanied by 2 Penjas teachers. The implementation of small-scale test runs smoothly, with a little constrained by hot weather factors. Small-scale test results, overall the teacher stated that the game model was good with a percentage of the score observed by learning implementation was $95 \%$. Overall the teacher of Education agreed that the game model was right to stimulate the skill of throwing the ball at the target of the child. This can be explained because the model offered can be played well by children. In addition the game model which consists of several components can improve the ability of manipulative motion in children.

Some inputs and suggestions were given by the teachers of the small-scale test results, namely the game model adapted to the number of hours of school lessons. Input is also given for the distance of the target is too far made closer so that students are more easily on the target (10 meters too far for elementary students). The teacher also provides input to clarify the game implementation instructions so that they are easy to implement. The input and suggestions provided by the teacher are used as a basis for improving and refining the learning model to be applied to large-scale tests.

The revised learning model is then applied to large-scale tests. Large scale tests were carried out at SDN 1 Jatimulyo and SD Semuten Dlingon Bantul. The students who were made as subjects were as many as 20 people in each school so that the total for large-scale tests used 40 students. The implementation of a large scale test at each school was accompanied by 2 teachers, namely 1 physical education teacher and 1 class teacher. Largescale large-scale test results show better results. The assessment results show the better game models developed in improving basic manipulative motion skills in children. The value of $\%$ of the assessment results increased to $98.125 \%$.

Overall it can be concluded that the ball throwing learning model on the target is appropriate to be used as an alternative game learning model to develop manipulative skills and learning motivation for lower grade elementary school students. The effectiveness of 
learning activities throwing the ball at the target to improve manipulative skills and learning motivation for lower-class elementary school students can be seen from the students' ability which increased from meeting 1 to meeting 3 . The results of the t-test analysis showed significant results of increased ability from meeting 1 to meeting 2 Ability is also seen from meeting 2 which is getting better during the 3rd meeting.

\section{Conclusion}

Based on the results of the study and discussion on the final product study that has been stated in chapter IV some research conclusions are formulated, namely:

1) The development steps used in developing learning activities throwing the ball at the target to improve manipulative skills for lower grade elementary school students consist of (1) the preliminary research phase which includes literature study and relevant research and field studies and (2) the development stage , (3) the expert validation stage, and (4) the stage of empirical validation stage by conducting small scale tests, the results of small scale tests are then continued on a large scale.

2) Learning activities throwing the ball at the target to improve manipulative skills for lower grade elementary school students that are developed, based on the results of the validation of the learning model experts include the contents of the material, implementation, language and format of writing stated to be very good. The model that has been declared feasible from expert validation is then implemented in a 2-stage small-scale test and 3stage large-scale test. Based on the results of validation and small-scale test, it was obtained a score of $95 \%$ with the effectiveness of $p=0,000$. In the large scale test, it was found that the score was $98.125 \%$ with the effectiveness of $p=0.000$. Based on these results it can be concluded that the developed model is suitable for use.

3) Based on the results of statistical tests it is known that there is a significant increase in manipulative basic motion from meeting 1 to meeting 3 . Based on the average value is known to be seen at meeting 3 at 3.76 increasing compared to meeting 1 at 2.27 and meeting 2 at 3.42 .

\section{References}

[1] A. Hadis, Psikologi dalam Pendidikan (Sangat penting untuk: Dosen, Guru, Mahasiswa, Orangtua, Masyarakat, dan Pemerhati Pendidikan. Bandung: Alfabeta, 2010.

[2] R. R. P. J. Buscemi, A. Kong, M. L. Fitzgibbon, E. E. Bustamante, C. L. Davis, "Society Of Behavioral Medicine Position Statement: Elementary School-Based Physical Activity Supports Academic Achievement," Transl. Behav. Med., vol. 4(4), pp. 436-438, 2014.

[3] P. M. A. D. Faigenbaum, "Medicine Ball Training for Kids: Benefits, Concerns, and Program Design Considerations," ACSMs. Health Fit. J., vol. 12(3), pp. 7-12, 2008.

[4] M. Widya, Pola Gerak Anak Usia Dini. Bandung: Direktori UPI, 2010.

[5] D. Mutiah, Psikologi Bermain Anak Usia Dini. Jakarta: Kencana, 2010.

[6] M. S. Tedjasaputra, Bermain, Mainan dan Permainan. Jakarta: Grasindo, 2010.

[7] A. Sucipto, "Mengembangkan Kecerdasan Majemuk (Multiple Intelligences) Anak Usia Dini Melalui Pembelajaran Pendidikan Jasmani," J. Paradig., vol. 13(25), pp. 219-229, 2008.

[8] W. R. B. M. D. Gall, J. P. Gall, Action research. Educational Research: An Introduction, Pearson Education. Boston: Pearson Education, Inc., 2003. 